
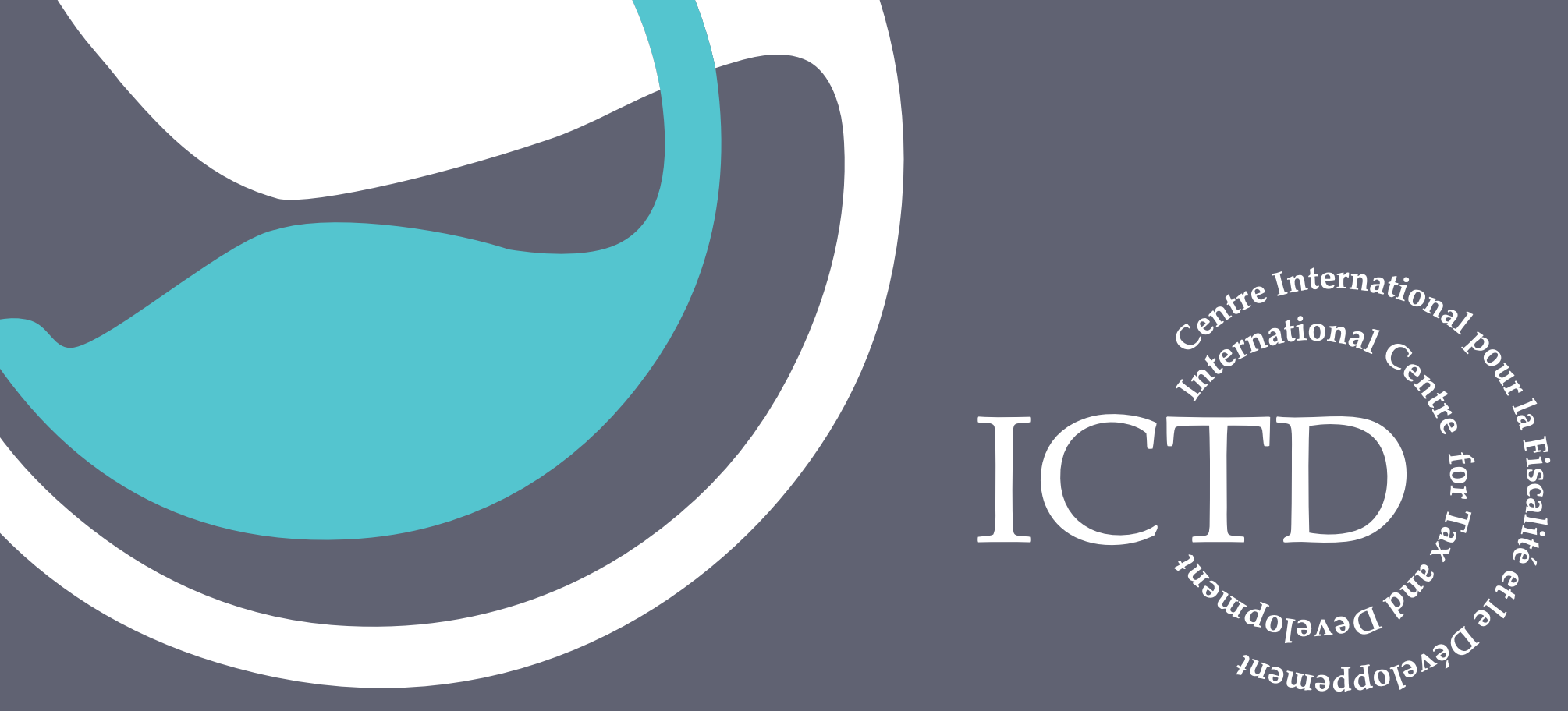

Working Paper 45

\title{
Boosting Revenue Collection through Taxing High Net Worth Individuals: The Case of Uganda
}

Jalia Kangave, Susan Nakato, Ronald Waiswa and Patrick Lumala Zzimbe January 2016 
ICTD Working Paper 45

Boosting Revenue Collection through Taxing High Net Worth Individuals: The Case of Uganda

Jalia Kangave, Susan Nakato, Ronald Waiswa and Patrick Lumala Zzimbe

January 2016 
Boosting Revenue Collection through Taxing High Net Worth Individuals: the Case of Uganda Jalia Kangave, Susan Nakato, Ronald Waiswa and Patrick Lumala Zzimbe ICTD Working Paper 45

First published by the Institute of Development Studies in January 2016

(C) Institute of Development Studies 2016

ISBN: 978-1-78118-285-7

A catalogue record for this publication is available from the British Library.

All rights reserved. Reproduction, copy, transmission, or translation of any part of this publication may

be made only under the following conditions:

- with the prior permission of the publisher; or

- with a licence from the Copyright Licensing Agency Ltd., 90 Tottenham Court Road, London W1P 9HE, UK,

or from another national licensing agency; or

- under the terms set out below.

This publication is copyright, but may be reproduced by any method without fee for teaching or nonprofit purposes, but not for resale. Formal permission is required for all such uses, but normally will be granted immediately. For copying in any other circumstances, or for reuse in other publications, or for translation or adaptation, prior written permission must be obtained from the publisher and a fee may be payable.

Available from:

The International Centre for Tax and Development

at the Institute of Development Studies

Brighton BN1 9RE, UK

Tel: +44 (0) 1273606261 Fax: +44 (0) 1273621202

E-mail: info@ictd.ac.uk

Web: www.ictd/en/publications

IDS is a charitable company limited by guarantee and registered in England (No. 877338) 


\title{
Boosting Revenue Collection through Taxing High Net Worth Individuals: the Case of Uganda
}

\author{
Jalia Kangave, Susan Nakato, Ronald Waiswa and Patrick Lumala Zzimbe
}

\section{Summary}

For over a decade Uganda's tax-to-GDP ratio hovered between 12 per cent and 13 per cent, despite various amendments to tax laws and reforms in tax administration. Part of the low revenue contribution can be attributed to factors external to the Uganda Revenue Authority (URA), such as the structure of the economy - particularly the prevalence of the informal sector and the ubiquity of cash transactions. Another explanation is that poor revenue collection is a result of factors internal to the URA. One of these factors is that the URA's enforcement efforts have concentrated on taxing corporate entities at the expense of individuals. With the exception of employees, very few individuals comply with their tax obligations outside those incurred at points of importation. Specifically, many wealthy individuals in the private and public sector either do not pay taxes or grossly under-declare their income. The consequence is that very little tax is being collected from this category of taxpayers.

This paper explores the potential for increasing tax revenue by taxing High Net Worth Individuals (HNWIs) through various lenses, including examining the legislative and administrative framework governing the taxation of individuals, collaborative efforts between the URA and other government agencies to improve tax administration, and mechanisms in place to support the sharing of taxpayer information both within the URA and with third parties. We highlight the strengths and weaknesses in the legal and administrative frameworks, with the underlying aim of designing an approach for taxing HNWIs. This paper discusses the findings of phase one of a two-phase project. The second phase will conduct a comparative study on taxation of HNWIs in other jurisdictions, with the aim of developing guiding principles for taxing Uganda's HNWIs.

Keywords: economic elites; exchange of information; gross domestic product; High Net Worth Individuals; tax administration; Uganda Revenue Authority.

Jalia Kangave is a Research Fellow at the Institute of Development Studies, University of Sussex. She was an independent tax and legal researcher at the time of writing the paper.

Susan Nakato is a supervisor in the Corporate Performance, Monitoring and Evaluation Department of the URA's Research, Planning and Development Division. She is also a lecturer at Kyambogo University, Uganda.

Ronald Waiswa is an officer in the Business Intelligence and Data Analysis - Joint Compliance Initiative at the URA. He is also a research associate at Lone international Development Agency (LiDA) - Uganda.

Patrick Lumala Zzimbe is an officer in Research, Statistics and Policy Analysis at the URA's Research, Planning and Development Division. 


\section{Contents}

Summary 3

Acknowledgements $\quad 6$

Acronyms 6

$\begin{array}{lr}\text { Introduction } & 7\end{array}$

1 Defining HNWls for Uganda's purposes: understanding the economic and socio-cultural terrain $\quad 10$

$2 \quad$ Legislative framework governing economic affairs of individuals 13

2.1 The Income Tax Act 13

2.1.1 Charging provisions 13

2.1.2 Anti-avoidance rules 14

2.1.3 Taxation of non-residents 14

2.1.4 Tax obligations, penalties and offences $\quad 14$

2.2 The Anti-Money Laundering Act 15

$3 \quad$ Translating policy into practice: administrative strengths and weaknesses 17

$\begin{array}{lll}3.1 & \text { Status of the URA } & 17\end{array}$

$\begin{array}{lll}3.2 & \text { Strengths in tax administration } & 18\end{array}$

3.2.1 The Taxpayer Register Expansion Project (TREP) 18

3.2.2 The Rental Project 18

$\begin{array}{ll}3.2 .3 & \text { The electronic tax system } \\ 3.2 .4 & 19\end{array}$

$\begin{array}{ll}\text { 3.2.4 The VIP taxpayer segment } & 19\end{array}$

$\begin{array}{ll}\text { 3.3 Shortcomings in tax administration } & 19\end{array}$

3.3.1 Taxation of individuals 20

3.3.2 Taxation of allowances $\quad 22$

3.3.3 Optimisation of Tax Identification Numbers (TINs) 22

3.3.4 Other disconnects between theory and practice 22

$4 \quad$ Management and exchange of information 23

4.1 Channels for sharing information 23

4.1.1 Sharing of information within the URA 23

4.1.2 Memoranda of Understanding 23

4.1.3 Exchange of information through Double Taxation
Agreements (DTAs)

4.1.4 Other sources of information 25

4.2 Obstacles to sharing information within the URA 25

4.2.1 Competing interests in URA departments 25

4.2.2 Weaknesses in automated processes 25

4.2.3 Limitations to accessing information from third parties 25

4.2.4 Accuracy and comprehensiveness of data 26

4.2.5 Capacity of URA officials to utilise data 27

$5 \quad$ Taxing HNWls in Uganda: a preliminary approach 27

$\begin{array}{lll}5.1 & \text { Approaches targeted at taxpayers } & 27\end{array}$

$\begin{array}{lll}\text { 5.1.1 Encouraging quasi-voluntary compliance } & 27\end{array}$

5.1.2 Dealing with non-compliance: tax education and tax amnesties 28

5.1.3 Dealing with deliberate non-compliance 29

5.2 Approaches targeting the URA and government 30

5.2.1 Building tax morale 30 
5.2.2 Tackling the problem of the informal sector 31

5.2.3 Strengthening capacity of URA officials 32

6 Conclusion: the way forward 32

References

\section{Graphs}

Graph 1

Uganda's rebased tax-to-GDP estimates 2009/10-2014/15

Graph 2

Informal sector share (Shs. million)

Tables

Table 1

Compliance of government officials and companies they are associated with

Table 2 Individual taxpayers' payment status 2013/14 (excluding PAYE)

Table 3 Individual taxpayers' customs payments vis-à-vis income tax payments 2013/14

Table 4

Compliance of top lawyers for individual income tax 


\section{Acknowledgements}

We are greatly indebted to the International Centre for Tax and Development (ICTD) for providing the funding that made this research possible. We thank our colleagues in the URA who contributed to this research in various respects, and all those who participated in this research through interviews. We take full responsibility for any errors contained herein.

\section{Acronyms}

ASYCUDA Automated System for Customs Data

DTA Double Taxation Agreement

EAC East African Community

FIA Financial Intelligence Authority

GDP Gross Domestic Product

HNWI High Net Worth Individual

ITA Income Tax Act

JCC Joint Compliance Committee

KCCA Kampala Capital City Authority

LTO Large Taxpayers' Office

MOU Memorandum of Understanding

OECD Organisation for Economic Cooperation and Development

PAYE Pay As You Earn

TIN Tax Identification Number

TREP Taxpayer Registration Expansion Project

URA Uganda Revenue Authority

URSB Uganda Registration Services Bureau 


\section{Introduction}

While net tax collection in many developing countries has increased over the years, their taxto-GDP ratios remain at less than 20 per cent - compared to the 30 to 45 per cent raised by their developed country counterparts (Moore 2013). In Uganda's case, tax contributions for the past decade have hovered between 12 per cent and 13 per cent of GDP, with the figures decreasing even further after rebasing (URA databases 2015). The poor tax performance can be attributed to a number of factors, including the structure of the economy, the existence of a large informal sector, and shortcomings in tax administration.

\section{Graph 1 Uganda's rebased tax-to-GDP estimates 2009/10-2014/15}

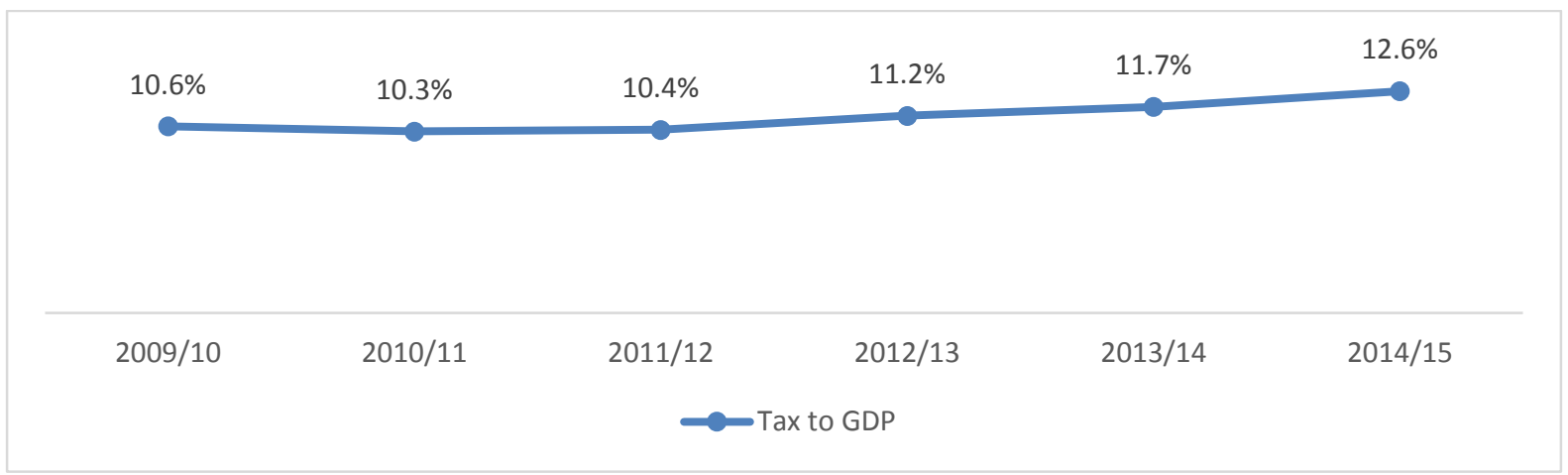

Source: URA databases 2015 and Uganda Bureau of Statistics 2014.

\section{Uganda's economic structure}

There is often a mismatch in Uganda between the contribution that different sectors make to taxation and their contribution to GDP. For example, the agricultural sector, which contributes the largest share to the country's GDP (27.21 per cent), contributes only 0.81 per cent to tax revenue (URA databases 2014). Other comparisons include the construction industry (8.01 per cent compared to 2.7 per cent), education (5.79 per cent compared to 1.75 per cent), and real estate (4.21 per cent compared to 1.36 per cent). There are various explanations for this mismatch, including the existence of a large informal sector, and the provision of tax exemptions to certain sectors such as agriculture and, until recently, education.

\section{The existence of a large informal sector}

As at June 2015, the informal sector was estimated to constitute 49 per cent of the country's GDP, with agriculture, wholesale and retail trade, construction and the transport sector being the most prevalent (Ministry of Finance, Planning and Economic Development 2015). In 2013, the World Bank reported that the non-agricultural informal sector employed 14 per cent of the country's labour force, of which 86 per cent were household-based jobs (World Bank 2013). Graph 2 illustrates the share of the informal sector for the past five years. 


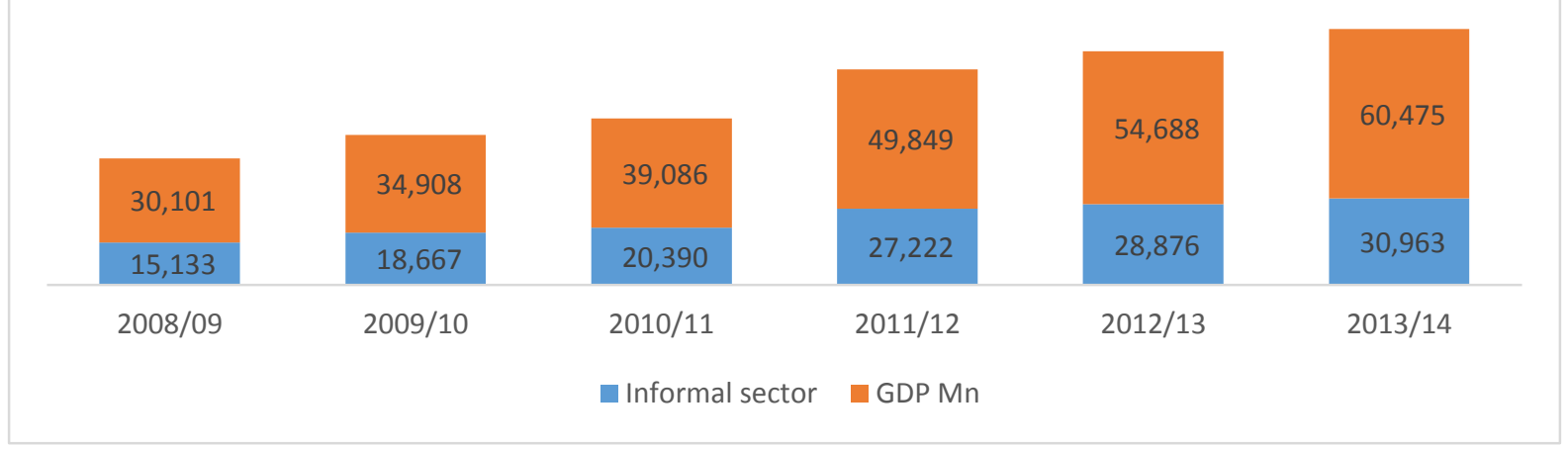

Source: URA databases.

The above statistics are important for a number of reasons. First, they underscore the fact that half of the country's productivity is non-institutionalised and hence difficult to tax.

Second, that agriculture (whether commercial or subsistence) is a huge part of the problem. What these statistics do not show is the extent to which large commercial enterprises are informal. We conceptualise this in Section 2.

The government has undertaken various tax initiatives aimed at curbing the prevalence of the informal sector. For example, in 2014, the Income Tax Act (ITA) was amended to raise the presumptive tax rate from 1 per cent to 3 per cent of gross turnover (Income Tax Act, Second Schedule; Ministry of Finance, Planning and Economic Development 2014). In the same year, the Taxpayer Registration Expansion Project (TREP) was introduced as a collaboration between the URA, the Kampala Capital City Authority (KCCA) and the Uganda Registration Services Bureau (URSB). We discuss the details of this project in Section 4. More recently, the government introduced withholding taxes on various sectors, particularly those operating in the transport sector (Ministry of Finance, Planning and Economic Development 2015).

\section{Shortcomings in tax administration}

In Sections 3 and 4, we discuss the strengths and weaknesses in the URA's operations. Suffice it to note here that a number of reforms have been made to tax administration, including the restructuring of the URA in 2004 to reflect functional ideals, automating some internal and external services, developing human capacity (including increasingly recruiting from the private sector), and re-engineering business processes.

Despite the introduction of these efficiency measures, revenue collection remains low. We argue that this is partly explained by the fact that, like in many other developing countries, personal income taxes remain largely untapped (Moore 2013; Mahon Jr. et al. 2015). In financial year (FY) 2013/2014, for example, only 4 per cent of the total tax collection was attributed to individuals (URA databases 2014). In the same period, individuals remitted less than 1 per cent of total domestic tax revenue, compared to the 8 per cent that they contributed to international trade taxes. The higher contribution to international trade taxes is largely explained by the stringent collection measures at border points. We believe that the extremely low level of individual contributions to domestic taxes is partly explained by an emphasis being placed on the taxation of companies, at the expense of taxing individuals. Part of the solution to this problem thus lies in managing the compliance of individuals generally, and wealthy individuals in particular.

The taxation of HNWIs has recently gained traction in many countries for various reasons (OECD 2009). First, these individuals often engage in complex commercial transactions. Second, they contribute (or have the potential to contribute) significantly to total tax revenue. 
Third, given their vast amounts of income and wealth, they are more likely to engage in aggressive tax planning schemes. Lastly, the compliance behaviour of this group of taxpayers is bound to have a bearing on the integrity of the tax system as a whole. Also, despite the 2008 global economic crisis, the population of HNWIs has continued to grow. It is estimated that, on average, the growth of HNWIs and their wealth globally is at 15 per cent and 14 per cent respectively (Capgemini and RBC Wealth Management 2014). In the United States, for example, the share of annual income earned by the top 1 per cent between 1976 and 2011 more than doubled from 9 per cent to 20 per cent (Alvaredo et. al. 2013).

Comparable increases in top income shares have been recorded in other Western Englishspeaking countries, and countries such as China and India (Atkinson et al. 2011). Similarly, conservative estimates suggest that, between the 1970s and 2010, private elites in 139 lowand middle-income countries accumulated between US\$7.3 trillion and US\$9.3 trillion in unrecorded offshore wealth (Henry 2012). While there is increasing concern surrounding the fact there have been significant tax cuts on the income of HNWIs in some high-income countries particularly after the 1980s (Piketty et al. 2014; National Economic Council 2012), there is at least some evidence that taxing these individuals can lead to significant boosts in revenue (OECD 2009). As at 2009, the top 0.5 per cent of taxpayers in the United Kingdom paid 17 per cent of total income tax. In Germany, the top 0.1 per cent paid 8 per cent, and in the United States, the top 1 per cent paid about 40 per cent of federal income taxes. Our hypothesis is that identifying and taxing Uganda's HNWIs will result in an increase in the contribution that individuals make to tax revenue specifically, and in the tax contribution to GDP more generally.

We investigate the potential promised by the taxation of HNWIs through various lenses. In Section 1, we conceptualise wealth in Uganda with the aim of understanding the nature of the economy and how wealth is amassed. Section 2 analyses the legal framework governing the taxation of individuals and regulation of huge cash transactions. Section 3 examines the extent to which tax administration has mirrored legal provisions. In Section 4, we appraise the various avenues for the sharing and management of taxpayer information. Section 5 proposes some preliminary recommendations on how to approach the taxation of HNWIs. The paper concludes in Section 6.

Our discussion is intended to serve various purposes. To begin with, it is aimed at acquainting the reader with the policy and legislative framework governing the taxation of individuals in Uganda. Second, it underscores some of the successes that have been achieved through the URA's attempts to improve tax administration, and flags areas where there is room for improvement. Third, we disseminate some statistics and narratives about tax administration which have hitherto largely been internal to the URA. We hope that this dissemination not only contributes to the body of literature on tax administration, but, perhaps more importantly, provides the groundwork for future conversations between tax administrators, taxpayers and other stakeholders, including those in the private sector, academia, other revenue authorities, non-governmental organisations and development partners.

We employed various methods in our research. We analysed a variety of texts, including academic articles, domestic laws, international agreements, parliamentary Hansards, reports and articles by international organisations, URA reports, newspaper articles and lifestyle magazines. Second, we conducted interviews with individuals in government agencies, including commissioners, managers and revenue officials in the URA, and officials from KCCA, Ministry of Finance, Financial Intelligence Authority and the Bank of Uganda. We also held interviews with representatives from the private sector, including tax consultants from two of the leading audit firms, a reputable tax lawyer, officials from a commercial bank, and a professor from the Makerere University School of Law. Lastly, using internal URA databases and some external data, we conducted various data matching exercises geared largely towards establishing the level of tax compliance. Internal data consisted of 
information on taxpayer registration, payments data, income tax returns data, audit data, stamp duty payments and motor vehicle data. Externally, we matched information from the KCCA's property register with that of the URA's rental register, to establish the comprehensiveness of the latter.

\section{Defining HNWIs for Uganda's purposes: understanding the economic and socio-cultural terrain}

HNWIs, also known as economic elites, high wealth or high income individuals, are defined differently in different contexts (DiCaprio 2014). The OECD observes that, while there is no universally accepted definition of HNWIs, various wealth reports associate these individuals with a net worth of at least US\$1 million held either directly or indirectly through controlled entities such as private companies and trusts (OECD 2009). In Australia, they are defined as individuals who, together with their associates, effectively control A\$30 million or more in net wealth (Australian Taxation Office 2008). Australia's HNWIs have been found to engage frequently in complex business arrangements, with their wealth being spread across groups of closely-held companies and trusts. For its part, the South African Revenue Service defines HNWIs as individuals with a gross income of at least R7 million and/or gross wealth of at least R75 million (South African Revenue Service 2012). A significant number of these individuals are believed to conceal their income in trusts (South African Revenue Service 2014).

While the URA introduced a HNWI category in July 2012 as part of the taxpayers handled by the Large Taxpayers' Office (LTO), it does not have a register of these individuals. Similarly, apart from designating HNWIs as large taxpayers, there is no definition or criterion that guides the determination of what makes one qualify to be a HNWI. As at January 2015, the LTO register had a total of 737 taxpayers, seventeen of whom were individuals (URA databases 2015). On 1 July 2015, in a move to provide more clarity on the definition of HNWIs, internal taxpayer segmentation was revised to add that these individuals will be identified by their net worth. The URA is yet to determine a threshold for this net worth. Some guidance can be drawn from the new LTO criteria, which defines large taxpayers as including the top fifty individuals based on tax contribution, and all taxpayers whose average annual tax contribution exceeds Shs. 4 billion (approximately US $\$ 1.44$ million). ${ }^{1}$

In the following discussion we focus on identifying the indicators of wealth in Uganda, and highlighting the strengths and weaknesses of the legislative and administrative frameworks governing taxation and relevant economic activities. We do not, for the purposes of this discussion, propose a threshold for HNWIs. This task is being kept for the second phase of the project for which this research is undertaken. As such, we refer to these individuals variously as wealthy individuals, potential HNWIs, economic elites and affluent individuals. We are aware that the lack of a working threshold may be perceived as a weakness in our research methodology. However, we find it more pertinent at this stage to focus on the substance of the principles that should guide taxation of these individuals, because these principles will subsequently have a bearing on determination of the threshold.

Any definition of HNWIs ought to be informed by an understanding not only of a country's economic structure, but also an appreciation of the manner in which wealth is amassed,

We use URA average exchange rates for FY 2014/15. At the time of writing, this rate was US $\$ 1=$ Shs.2,786.97. 
preserved and safeguarded in that country. To this end, it is important to understand Uganda's social-cultural setting, because this has at least some bearing on defining symbols of wealth. Our aim in this part of the paper is to develop a conceptual and theoretical base that is helpful in contextualising wealth on the one hand, and providing the groundwork for developing a comprehensive framework for taxing HNWls on the other hand.

Uganda is largely a 'real property' economy. By this, we mean that, instead of depositing money in bank accounts or investing in instruments such as shares and bonds, most individuals invest in physical structures, such as land and buildings. A 2013 survey of 4,032 households in rural and urban Uganda found that only 20 per cent of the adult population operated a bank account (Economic Policy Research Centre 2013). While 68 per cent of the population saved money, only 19 per cent of those were saving their money in formal banks. As far as Uganda's wealthy individuals are concerned, the richer they become, the more commercial structures they put up (Murangira 2014). Interviews with those working on the URA's Rental Project, for example, revealed that while many wealthy individuals are traders who deal in the import and export of goods, most of the proceeds from their businesses appear to be invested in real estate (Interviews with URA officials). Similarly, even professionals, such as lawyers, doctors, architects and engineers (whose primary source of income is from the provision of professional services), often subsequently invest their earnings in land and commercial buildings. This is not to suggest that there are no other important indicators of wealth in Uganda. There are, for example, wealthy individuals dealing in manufacturing, construction and commercial agriculture (Interview with Professor at Makerere University). There are also individuals whose wealth is attributed to their directorships and shareholdings in some of the top taxpaying companies (Interview with Tax Consultants; Interview with URA official). URA records as at January 2015 indicate, for example, that sixteen individuals hold directorships in more than five of the top taxpaying companies (URA databases 2015). These individuals are potential HNWIs. In the end, however, many of them reinvest their earnings in land and commercial properties. Even inheritance, which was identified as an important source of wealth for some affluent members of society, often comes in the form of land and buildings (Interview with Professor at Makerere University).

There is a slight difference between the symbols of wealth in rural and urban Uganda. In urban areas, such as Kampala, wealthy individuals invest mostly in commercial properties. In many rural areas, the symbols of wealth include large chunks of (agricultural) land and livestock. In Ankole, for example, cattle serve as a 'living bank', in the sense that they are held not only to meet household consumption needs, but also to be sold when families need to meet larger expenses such as school fees and medical bills (Wurzinger et al. 2008). However, even for those whose wealth is defined by livestock, land invariably constitutes a central component of this wealth, because the more livestock (particularly cattle) one has, the more grazing land is required. Consequently, while our research identified various categories of wealth and income sources for potential HNWIs, and while it is important for the URA to investigate these sources, the primacy of land and buildings as a source of amassing and preserving wealth cannot be overemphasised. To this end, any attempt to identify and define HNWls for Uganda's purposes has to rely significantly on the development of a comprehensive and up-to-date register of land and commercial properties.

Second, as noted in the Introduction, Uganda has a huge informal sector, and many individuals thrive in this informality. There is often a tendency to equate the informal sector with micro-enterprises and unskilled labour. While it is true that a significant proportion of those operating informally are small businesses, it is also true that, increasingly, there is a small proportion of very wealthy individuals who have thrived precisely because they have remained informal. Their businesses have various characteristics: they transact mainly in cash, do not keep proper books of account, are not registered with government agencies, many do not deposit their money in bank accounts, and they have less than five employees 
(Interviews with URA officials; Uganda Bureau of Statistics 2009). Frequently, the business owners have little formal education, but make thousands of millions of Ugandan shillings on a daily basis; for most, the only taxes that they pay are those paid on importation (Interview with Tax Consultants). Having said that, the informal sector in Uganda is not necessarily synonymous with unskilled labour. There is also a large informal sector within the formal sector. By this we mean that there are many professionals - both in the private and public sector - who may pay taxes on their employment income and/or importation of goods, but take advantage of the loopholes created by the informal sector to undertake additional lucrative commercial enterprises on which they do not pay taxes. This informal income which sometimes is much more than their formal income - is derived from activities such as letting out commercial properties, operating fleets of commercial vehicles, running hardware stores, and, increasingly, engaging in commercial agriculture (Interviews with URA officials).

HNWIs often possess political capital. Fairfield observes that economic elites have two kinds of power: instrumental power and structural power (Fairfield 2010, 2013). Instrumental power relates to the ability of these individuals to use political action (such as lobbying) to influence government policies. This power emanates from concerted efforts between business persons and government officials, the recruitment of business elites into important government positions, and the establishment of partisan linkages between business people and political parties. Structural power, on the other hand, is less direct. It does not rely on any action being undertaken by the business community. Rather, it is driven by a threat that policy reforms will result in decreased investment or lead to capital flight.

For the purposes of Fairfield's discussion, economic elites are distinct from political elites. The former use their structural and instrumental power to influence the actions of the latter. In Uganda's case, there is an additional layer of complexity. There are those economic elites who could loosely be referred to as 'pure economic elites' - pure in the sense that they are business persons and professionals whose economic resources give them access to policymakers and government executives, hence facilitating tax bargains (Kangave and Katusiimeh 2015). These individuals possess both structural and instrumental power, but they are neither politicians nor civil servants. The second category is a less traditional one, but perhaps results in the most significant fiscal footprint. It consists of civil servants and politicians as potential HNWIs. While the official salaries of these individuals are often quite modest, some of them amass significant amounts of wealth through unexplained sources, and yet do not pay taxes on this wealth, even after it has been invested (Interviews with URA officials). Corruption scandals, for example, reveal huge sums of money that are embezzled by public servants, including: US $\$ 12.7$ million of donor funding that was given to the Office of the Prime Minister in 2012; US\$4.5 million of the Global Fund to Fight AIDS, Tuberculosis and Malaria in 2005; US\$800,000 from the Global Alliance for Vaccines and Immunisations in 2006; US\$2.4 million for the 2007 Commonwealth Heads of Government Meeting (Human Rights Watch 2013). Similarly, an analysis of the URA taxpayer databases reveals a number of government officials associated with various commercial enterprises, such as schools, hotels, media houses, and land worth billions of shillings (URA databases 2011-2014) However, the majority of these individuals do not pay income taxes. Also, most of the companies they are associated with do not comply with their tax obligations.

Table 1 Compliance of government officials and companies they are associated with

\begin{tabular}{|l|l|l|l|}
\hline & FY 2011/12 & FY 2012/13 & FY 2013/14 \\
\hline Total number of officials & 71 & 71 & 71 \\
\hline Paid individuals' taxes & 0 & 0 & 1 \\
\hline Number of companies & 56 & 56 & 56 \\
\hline Paid corporation tax & 9 & 9 & 17 \\
\hline Did not pay corporation tax & 47 & 47 & 39 \\
\hline \\
Source: URA databases.
\end{tabular}


Lastly, it has been suggested that HNWIs are more likely than other taxpayers to engage in aggressive tax planning, given the vast amount of their wealth (OECD 2009). In addition, these individuals are quite likely to recruit the services of financial experts, who assist in designing the aggressive tax planning strategies. In Uganda's case, there is little likelihood of this happening. There are a few cases of individuals who may attempt to split their income so that they are taxed at lower tax rates, either by arranging that part of their income is paid outside Uganda or by splitting wealth between family members, particularly spouses and children (Interview with Tax Consultants). Also, the tax burden of highly salaried individuals may be reduced by paying their income in the form of management fees offshore: this would attract an effective tax rate of 15 per cent, compared to an effective 40 per cent rate if it is paid as employment income. On the whole, however, almost all those who were interviewed attested to the fact that, at least as far as individuals are concerned, Uganda's taxpayers rarely engage in aggressive tax planning. Rather, they are more correctly defined as engaging in aggressive tax evasion. This means that most of them simply do not pay taxes or grossly under-declare their income. Even the big four audit firms in Uganda, ${ }^{2}$ which are in a position to provide advice on tax planning, rarely have individuals as their clients (Interview with official from Ministry of Finance). Consequently, the solution for the URA as far as this group of taxpayers is concerned, should not so much be geared towards strengthening technical capacity to identify aggressive tax planning schemes. Rather, it should be about strengthening technical capacity to undertake audits where there is scant information, and developing mechanisms for detecting cases of evasion.

\section{Legislative framework governing economic affairs of individuals}

There are two main laws having a bearing on the affairs of affluent individuals in Uganda: the Income Tax Act and the Anti-Money Laundering Act.

\subsection{The Income Tax Act}

There is no specific law governing the taxation of HNWIs in Uganda. However, there are various provisions in the Income Tax Act (ITA) that have a bearing on the commercial activities of individuals. These provisions can loosely be divided into charging provisions, general anti-avoidance rules, provisions relating to the taxation of non-residents, and those dealing with offences, penalties and the obligation to pay taxes.

\subsubsection{Charging provisions}

The ITA imposes a tax on every individual earning rental income (Section 5), employment income (Section 19), business income (Section 18), and property income (Section 20). Uganda uses a residence-based system of taxation where residents are taxed on all their worldwide income, while non-residents are taxed on income sourced in Uganda. Section 9 of the ITA defines a resident individual for tax purposes. There are four tax bands for resident individuals, and three bands for non-residents. 
The income tax rates applicable to the annual income of resident individuals are:

\begin{tabular}{|l|l|}
\hline Chargeable income & Rate of tax \\
\hline Not exceeding Shs.2,820,000 & $0 \%$ \\
\hline Exceeding Shs.2,820,000 but not exceeding Shs.4,020,000 & $10 \%$ of the income exceeding Shs.2,820,000 \\
\hline Exceeding Shs.4,020,000 but not exceeding Shs.4,920,000 & $\begin{array}{l}\text { Shs. } 120,000 \text { plus } 20 \% \text { of the income exceeding } \\
\text { Shs.4,020,000 }\end{array}$ \\
\hline Over Shs.4,920,000 & $\begin{array}{l}\text { a. Shs.300,000 plus } 30 \% \text { of the income exceeding } \\
\text { Shs.4,920,000; } \\
\text { b. Where the chargeable income exceeds Shs. } 120,000,000, \\
\text { an additional } 10 \% \text { is charged on the amount by which the } \\
\text { chargeable income exceeds Shs. } 120,000,000\end{array}$ \\
\hline
\end{tabular}

The income tax rates applicable to the annual income of non-resident individuals are:

\begin{tabular}{|l|l|}
\hline Chargeable income & Rate of tax \\
\hline Not exceeding Shs.4,020,000 & $10 \%$ \\
\hline Exceeding Shs.4,020,000 but not exceeding Shs.4,920,000 & $\begin{array}{l}\text { Shs.402,000 plus 20\% of the income exceeding } \\
\text { Shs.4,020,000 }\end{array}$ \\
\hline Over Shs.4,920,000 & $\begin{array}{l}\text { a. Shs.582,000 plus } 30 \% \text { of the income exceeding } \\
\text { Shs.4,920,000; } \\
\text { b. Where the chargeable income exceeds Shs. } 120,000,000, \\
\text { an additional } 10 \% \text { is charged on the amount by which the } \\
\text { chargeable income exceeds Shs. } 120,000,000\end{array}$ \\
\hline
\end{tabular}

\subsubsection{Anti-avoidance rules}

The ITA contains provisions aimed at deterring taxpayers from engaging in aggressive tax planning. Section 64, for example, provides that the URA can adjust the chargeable income of an individual where the individual attempts to split income with an associate either through transferring property directly or indirectly to the associate with the aim of lowering the tax payable by the transferor or the transferee. An associate is defined in Section 3 as a person who, 'not being an employee, acts in accordance with the directions, requests, suggestions, or wishes of another person, whether or not they are in a business relationship and whether those directions, requests, suggestions, or wishes are communicated to the first-mentioned person'. This provision is particularly useful because many affluent individuals in Uganda hold their properties in the names of their children and/or spouses (Interview with URA officials and officials from the Banking Sector). Similarly, Section 90 of the ITA gives the URA power to distribute, allocate and apportion income, deductions or credits between associated parties in order to reflect the arms-length principle. Lastly, under Section 91, the URA can re-characterise a transaction or an element of a transaction that was entered into as part of a tax avoidance scheme.

\subsubsection{Taxation of non-residents}

HNWIs do not have to be resident in Uganda. Any income sourced in Uganda by nonresidents is subject to tax. Some of the provisions on the taxation of non-residents that may have a bearing on commercial activities of HNWIs are those relating to contractors and professionals under Uganda-sourced service contracts (Section 85), or other international payments such as dividends, interest, royalties and rents paid to non-residents (Section 83). It is also important to study the list provided in Section 79, which outlines instances when income belonging to a non-resident is deemed to be sourced in Uganda.

\subsubsection{Tax obligations, penalties and offences}

Extant literature on the taxation of economic elites specifically and effective tax systems generally acknowledges that a good tax system should rely on quasi-voluntary compliance (Everest-Phillips 2009; Moore 2013). 'It is voluntary because taxpayers choose to pay. It is 
quasi-voluntary because coercion will be used against non-compliers if they are caught' (Therkildsen 2001). For this reason, even those tax administrations that have relatively high compliance rates maintain penalty regimes to serve as a deterrent to non-compliance (OECD 2009). Uganda has a self-assessment system of taxation (Section 96), where taxpayers are required to file returns for each year of income. The URA is allowed to audit returns within five years of the return being filed (Section 95). Where the taxpayer fails to furnish a return or the URA is not satisfied with a return that has been filed, the latter may use their best judgement to make an assessment of the chargeable income of the tax payer and the tax payable thereon (Section 95). Tax, when it becomes due, is a debt to the government, which can be sued for or recovered in a court of competent jurisdiction (Section 104). The law also allows the URA to recover taxes from a third party owing money to the taxpayer, or someone holding money on behalf of the taxpayer (Section 106). Lastly, the URA can undertake distress proceedings against the taxpayer's property (Section 107).

It is an offence for a taxpayer to fail to furnish a tax return (Section 137), to fail to keep proper records (Section 139), and to make false or misleading statements (Section 142). These offences are punishable by fines and/or imprisonment. Similarly, where taxes remain unpaid, interest is charged on the unpaid tax (Section 136).

\subsection{The Anti-Money Laundering Act}

Existing studies note that, while most of the income of HNWIs is held onshore, there is still a significant amount held in offshore accounts (OECD 2009). Worse still, those HNWIs engaging in aggressive tax planning schemes also often engage in offshore tax evasion (OECD 2009). As at 2010 , one study estimated that at least US $\$ 21$ trillion to US $\$ 32$ trillion in private wealth escaped tax by being invested in offshore secrecy jurisdictions (Henry 2012). It is also estimated that between the 1970s and 2008, cumulative capital flight from Africa amounted to US\$854 billion (Global Financial Integrity 2010). In Uganda's case, conservative estimates put illicit financial flows at 3 per cent of GDP (High Level Panel 2015). While the illicit financial flows in Africa have been mostly attributed to the activities of large corporations and organised crime (High Level Panel 2015), there is evidence of a rapidly growing number of HNWIs in Africa whose wealth is often invested abroad (Knight Frank 2014; Capgemini and RBC Wealth Management 2013). Those interviewed for this project agreed that, while Uganda's wealthy individuals keep most of their money in the country, there is some known and a lot more unknown wealth that is likely invested abroad particularly in bank accounts (Interviews with URA officials and tax consultants). The early 2015 leaking of bank account files of an HSBC Swiss subsidiary, which revealed that there were $57 \mathrm{HSBC}$ clients associated with Uganda who held a total of \$89.3 million in bank deposits, is just one example of offshore investments (Sserunjogi 2015). Similarly, 2011 parliamentary proceedings contain allegations of three government officials being bribed by companies in the oil sector (Parliament of Uganda 2011a). There were allegations that oil companies wired millions of euros to offshore accounts in the United Arab Emirates and United Kingdom using various conduits, including shell companies and bank accounts in other jurisdictions.

The primary legislation governing large cash transactions and illicit financial flows is the AntiMoney Laundering Act. Section 6 of the Act requires that bank accounts should be kept in the names of the account holders, instead of anonymous accounts or accounts held in fictitious or incorrect names. In the case of politically-exposed persons, banks are required to monitor the transactions of these individuals, take reasonable steps to establish the source of their wealth or income, and monitor their business relations with these individuals (Section 6). These provisions are quite relevant given our observation that some of Uganda's potential HNWIs are political figures. 
Section 6 (h) provides that, in cases of cross-border correspondent banking, banks should undertake due diligence measures, including gathering information about the respondent institution's reputation, access their anti-money-laundering financial controls, be satisfied that their due diligence measures in relation to customers are sufficient, reject correspondent relationships with shell banks, and obtain approval from senior management prior to entering into correspondent relationship. Under Section $6(\mathrm{k})$, banks are required to develop programmes that support the detection of money laundering, including policies and procedures for screening employees, conduct on-going employee training, and establish audit functions that test the effectiveness of the systems. There is also a requirement under Section 7 for banks to retain identity records of clients for at least ten years, and maintain the customer's identity and other business transactions for at least five years after closure of business.

The Anti-Money Laundering Act requires that cash or monetary transactions exceeding Shs.20 million (US\$7,176) should be recorded on a prescribed form, which banks should maintain for a period of ten years from the date of the transaction (Section 8). In the case of currency or monetary instruments in excess of Shs.30 million (US $\$ 10,764)$ that cross borders without going through the normal banking procedures or Uganda's financial banking systems, there is a requirement for the person intending to make the transfer to inform the URA before making the transfer (Section 9). The URA is then immediately required to forward a copy of the form to the Financial Intelligence Authority (FIA).

The establishment of the FIA is provided for under Section 18 of the Act. The FIA is tasked with combatting money laundering, including enhancing public awareness on the issue, making collected information available to competent authorities, and exchanging information with other countries that have treaties with Uganda (Section 19). It has powers to receive information relating to money laundering, collect information that it considers relevant, and to retain it for a period that it deems fit (Section 37).

The law tasks banks with taking note of suspicious (complex, unusual or large) transactions, transactions undertaken on behalf of persons whose identity has not been properly established, business relationships in countries that have no proper anti-money laundering controls, and electronic fund transfers that do not have proper originator information (Section 9). Where banks suspect that transactions are being undertaken for the purpose of evading taxes, they should seek further information on the identity of the transacting parties, the purpose of the transaction, the origin and destination of the money, and its ultimate beneficiary. These suspicious transactions should be reported to the FIA not later than two working days from the day of the suspicious transaction.

There are various offences contained in the Act, including engaging in, aiding or abetting money laundering activities (Section 116); tipping off a person that information regarding them has been requested, furnished or reported to the FIA (Section 117); falsifying, concealing or destroying documents relevant to a money laundering investigation (118); failing to keep records in the manner prescribed by the Act (Section 120); facilitating money laundering (section 121); destroying or tampering with records (Section 122); refusing to give assistance to the FIA (Section 123); failing to report required cash transactions (section 124); failing to report suspicious or unusual transactions (Section 125); failing to report cross-border cash transfers (Section 126); and not making reports to the FIA (Section 127). Penalties under the Act include imprisonment not exceeding fifteen years, or fines not exceeding Shs.2 billion (approximately US\$0.72 million) (Section 136).

The combination of the ITA and the Anti-Money Laundering Act provide for a robust legal framework for dealing with the economic affairs of HNWIs generally and their taxation in particular. However, it is one thing to have a strong legal framework, and quite another to 
ensure that provisions of the law are translated into practice. The next section discusses the practical application of these laws.

\title{
3 Translating policy into practice: administrative strengths and weaknesses
}

\author{
in poor country settings, ... actual tax policy is strongly influenced by the operations \\ of the tax administration \\ Therkildsen 2001 \\ tax administration is tax policy \\ de Jantcher 1990
}

\subsection{Status of the URA}

The URA was established in 1991 as a semi-autonomous revenue agency in charge of administering tax laws, including assessing, collecting and accounting for revenue (Uganda Revenue Authority Act, Cap 196). In addition, the body was tasked with advising the Minister of Finance on revenue implications, tax administration and policy issues relating to revenue. The semi-autonomous status it enjoys means that the URA is independent of civil service rules and regulations. This has allowed it flexibility relating to aspects such as its organisational structure, staffing, salaries and incentives, procurement and budgeting.

At the same time, because it is not fully independent, the URA remains under the general supervision of the Ministry of Finance. Under the URA Act, for example, the Minister of Finance has powers to:

- Appoint the chairperson and three other members of the URA's Board of Directors. Similarly, the minister has the power to suspend or terminate appointments of board members;

- Provide guidance on how the Board should perform its functions;

- Appoint and terminate the appointment of the URA's Commissioner General (in consultation with the Board); and

- Authorise the percentage of collected revenue to be retained by the URA to meet its expenditure budget.

Lastly, the minister sets performance targets for the URA every year in the form of amounts to be collected in tax revenue (Kangave 2005).

The URA's status is important to the taxation of HNWIs for various reasons. On the one hand, its semi-autonomous nature means that it has independence in its tax administrative duties, unlike previously where revenue administration was integrated in the functions of the Ministry of Finance. This independence is particularly important because of the politics that we have identified surrounding the taxation of HNWIs. On the other hand, semi-autonomy implies only partial autonomy, meaning that the likelihood of political interference remains high. That the Commissioner General - the head of the URA - and a significant proportion of board members are appointed by and can be dismissed by the Minister of Finance provides room for political interference into the affairs of the URA, and could have a bearing on any strategies aimed at taxing politically-connected persons such as HNWIs. 


\subsection{Strengths in tax administration}

A strong legislative framework does not guarantee an effective tax system. The URA has undertaken various reforms in tax administration in a bid to translate the law into practice. Some of these reforms are highlighted in the introduction. We highlight additional reforms below. These initiatives are important insofar as they provide infrastructure that is useful to support the taxation of HNWIs.

\subsubsection{The Taxpayer Register Expansion Project (TREP)}

In 2013, the Minister of Finance proposed that the URA, local governments, KCCA and URSB should collaborate in the identification of taxpayers and collection of taxes (Ministry of Finance, Planning and Economic Development 2013). This move was intended to widen the tax base, particularly by registering small businesses. In January 2014, the URA, KCCA and URSB commenced an operation - TREP - to streamline business registration (Uganda Revenue Authority undated; Ssempebwa 2014). Under TREP, the parties use a single registration form (based on KCCA's ECITIE system) to capture business information, which is shared between the parties on a weekly basis (TREP Report 2015).

The URA hopes to use TREP to expand its taxpayer register by adding an additional 103,570 taxpayers, who will contribute an additional Shs.12.9 billion (approximately US $\$ 4.63$ million) to tax revenue (Uganda Revenue Authority, undated; Ssempebwa, 2014). Initial success was registered through the 'Operation Storm Kampala' exercise; this enabled the URA to use information provided by KCCA to storm prominent shopping malls and register a number of businesses that were not on the URA's tax register. As at June 2015, TREP had added a total of 47,647 taxpayers onto the URA tax register (TREP Report 2015). While the main objective of TREP is to reduce the informal sector, particularly by identifying and taxing small businesses, this exercise is likely to result in the identification of businesses that may be small in terms of physical size, but have huge gross turnovers. Some of the individuals running these businesses would fit our definition of HNWIs who have thrived because of the informality.

\subsubsection{The Rental Project}

Since its enactment in 1997, the ITA provided for taxation of rental income. However, this provision of the law was rarely implemented. In 2014, Section 2 of the ITA was amended to define rental income as income derived by persons (as opposed to individuals). Prior to this, rental tax was imposed only on individuals; other legal persons had their income from letting out of properties categorised as business income. The URA suggested the amendment to the Ministry of Finance, following the realisation that a number of individuals were concealing their income through companies because the latter enjoyed a more favourable tax regime (Interview with Ministry of Finance official). It was thus hoped that a single regime would plug any existing loopholes.

In July 2014, the URA announced that it would begin collecting taxes on all rental houses and properties located in urban areas (Mulondo 2014). In the same month, the URA's Rental Project was started to concentrate on generating a property register and increasing revenue collections from this tax head. As at 2 January 2015, the property register had 9,606 properties (URA databases 2015). Given the intimate relationship between Uganda's wealthy individuals and real property, a robust register of commercial properties will be central to increasing revenue collection from this group of taxpayers. 


\subsubsection{The electronic tax system}

The electronic tax system (e-tax) was introduced by the URA in 2009, with the objective of easing and improving tax compliance through online registration, filing of tax returns and payment of taxes (Tata Consultancy Services 2011). This system was also intended to facilitate information sharing between URA departments by providing a 'single and integrated view of the taxpayer'. Sharing of information within the URA is made possible through built reports that are geared towards facilitating automatic matching of taxpayer information possessed by the URA's different departments (Interview with URA Official). Through these reports, authorised personnel are able to observe automatic links of transactions undertaken by registered taxpayers. For example, it is possible to automatically match data on a VAT declaration for inputs with information on the supplier of the inputs, and to establish whether the latter has met their tax filing obligations and is declaring the correct amount of output VAT. It is also possible to automatically match information on amounts claimed for input VAT with expenditure claimed under corporation tax or individual income taxes. Until recently, automatic matches could be made between direct taxes and customs duties under the Automated System for Customs Data++ (ASYCUDDA++). However, with the switch to ASYCUDDA World, the e-tax team is still working on the automatic interface between the new customs system and domestic taxes. At the time of writing, the domestic tax department was receiving data from ASYCUDDA World through dynamic reports that were manually generated.

The developments in the e-tax system are of great relevance to improving tax administration generally and increasing revenue from HNWIs. For example, in FY 2012/2013 the URA had 2.3 million visits to its web portal, up from 1.3 million in the previous year (Banage 2013). During the same period, the e-tax system recorded 4,417,245 transactions and collected Shs. 6 trillion (approximately US $\$ 2.15$ billion), which accounted for 75 per cent of collected revenue.

\subsubsection{The VIP taxpayer segment}

Effective 1 July 2015, the URA introduced a segment of taxpayers known as the VIP Group, consisting of two categories of individuals. The first category is powerful government officials, including the president of Uganda, the vice president, cabinet ministers, certain judicial officers, the speaker and deputy speaker of Parliament, kingdom heads, heads of political parties, heads of government institutions, the inspector general of police and chief of defence forces. The second category is composed of individuals who have the potential to influence large masses without necessarily being political or cultural figures. These include heads of professional associations, heads of business associations, heads of foreign business investors, religious leaders, individuals in offices that impact on URA businesses and outspoken individuals (including activists, journalists, religious and political figures). These two categories of individuals will be accorded special treatment by the URA, and their matters will be treated with a 'high level of security'.

VIPs as defined by this new segmentation are not necessarily HNWIs. However, as demonstrated in Section 1, they are potential HNWIs because of the quintessential link between politically-exposed persons and wealth in Uganda. The new segmentation, if administered effectively, will also be a useful channel for encouraging conversations between the URA and this group of individuals to encourage tax compliance.

\subsection{Shortcomings in tax administration}

While there have been various reforms to tax administration, there are still a number of shortcomings that undermine revenue collection. A few examples suffice. 


\subsubsection{Taxation of individuals}

Despite the fact that the ITA provides for the taxation of individuals, and that individuals account for 92.5 per cent of the taxpayer register (URA databases 2015), in practice little attention is paid to their taxation (Interviews with URA officials; Interview with tax consultants). Most of the URA's enforcement measures concentrate on companies (Interviews with URA officials). There are a number of issues that warrant special attention as far as taxation of individuals is concerned:

a. 68 per cent of individuals on the taxpayer register are employees. The remaining 32 per cent consist of business persons (15 per cent), individuals earning rental income (1 per cent), and other income (16 per cent). ${ }^{3}$ The high percentage attributed to employees is testimony to the importance of withholding taxes in facilitating compliance. However, our research found that even employment income is still under-reported, and the URA's enforcement measures still fall short in this regard. For example, even though the ITA has always defined employment income to include the directorship of a company, it was not until 2013 that the URA started enforcing the provisions of the Act to require directors either to pay taxes through Pay As You Earn (PAYE) or to file individual income tax returns (Interview with URA official). Before 2013, the URA's focus was on companies as legal persons, with limited, if any, attention being paid to the individuals managing the companies. And while directors are now required to file returns, there is still a strong belief within the URA that these individuals under-declare their income, particularly when one takes into account company profits and taxes paid on the same (Interview with URA official). For example, the payments data relating to FY 2013/2014 indicates that only 5 per cent of directors remitted income tax, with some remitting as little as Shs.15,000 (approximately US\$5.38), despite the fact that their companies were among the top taxpayers for that year; ${ }^{4}$

b. Registration for taxes does not necessarily translate into payment of taxes. With the exception of employees, most other individuals who are registered for tax purposes do not honour their tax obligations. In FY 2013/2014, for example, only 13 per cent of the individuals on the tax register (i.e. those earning rental income, business income and other income) remitted some payment to the URA (URA databases 2014).

Table 2 Individual taxpayers' payment status 2013/2014 (excluding PAYE)

\begin{tabular}{|l|c|l|}
\hline Made a payment & 26,942 & $13.0 \%$ \\
\hline Did not pay & 180,962 & $87.0 \%$ \\
\hline Total registered & 207,904 & $100.0 \%$ \\
\hline
\end{tabular}

Similarly, there is a mismatch between individuals who pay customs duties and those who pay income tax. For example, as Table 3 shows, in FY 2013/2014 four individuals paid over Shs. 1 billion in customs taxes, but only two of these paid income tax (URA Payments Data 2013/2014). In addition, twelve individuals paid over Shs.500 million (approximately US $\$ 179,406$ ) in customs duties, but none of these remitted income tax.

'Other income' caters for individuals who are on the register for purposes such as vehicle transfers and importation. Our analysis identified 16 individuals who were a director of at least 5 of the top taxpaying companies. 
Table 3 Individual taxpayers' customs payments vis-à-vis income tax payments 2013/2014

\begin{tabular}{|c|c|c|c|c|c|c|}
\hline \multicolumn{3}{|c|}{ FY $2013 / 14$} & \multicolumn{2}{|l|}{ FY $2012 / 13$} & \multicolumn{2}{|l|}{ FY 2011/12 } \\
\hline Custom tax paid & $\begin{array}{l}\text { Total number of } \\
\text { taxpayers }\end{array}$ & $\begin{array}{l}\text { Paid income } \\
\text { tax }\end{array}$ & $\begin{array}{l}\text { Total number of } \\
\text { taxpayers }\end{array}$ & $\begin{array}{l}\text { Paid income } \\
\text { tax }\end{array}$ & $\begin{array}{l}\text { Total number of } \\
\text { taxpayers }\end{array}$ & $\begin{array}{l}\text { Paid } \\
\text { income tax }\end{array}$ \\
\hline$>1$ bn & 4 & 2 & 3 & 1 & 3 & 2 \\
\hline $500 \mathrm{~m}-1 \mathrm{bn}$ & 12 & 0 & 16 & 4 & 6 & 2 \\
\hline $100 \mathrm{~m}-500 \mathrm{~m}$ & 374 & 64 & 445 & 31 & 43 & 14 \\
\hline $50 m-100 m$ & 809 & 88 & 734 & 28 & 57 & 19 \\
\hline$<50 \mathrm{~m}$ & 25,743 & 7,057 & 17,473 & 3,016 & 2,782 & 576 \\
\hline Grand total & 26,942 & 7,211 & 18,671 & 3,080 & 2,891 & 613 \\
\hline
\end{tabular}

c. With the exception of employment income, government officials rarely pay taxes on their other income-generating activities. Too frequently, even the companies that they own are not compliant with their income tax obligations. Our analysis of the URA's e-tax system identified government officials owning assets worth billions of shillings including schools, hotels and media houses. We studied seventy-one top-ranking government officials. Only one of the seventy-one officials has ever remitted individual income tax, and only a few of the 56 companies with which these individuals are associated remitted corporation tax in the years under review. Table 2 above highlights the poor taxpaying culture of these government officials and the companies they are associated with for financial years between 2011 and 2014.

d. URA officials who we interviewed acknowledged the fact that, while various professionals such as lawyers, doctors, architects and engineers are likely to be HNWIs, the URA has been lax in auditing their compliance. Of the eleven individuals identified by CEO Magazine as being some of Uganda's billionaires under forty years of age, two were lawyers and one a doctor (Nyambura 2015). Part VIII of the ITA provides for the taxation of partnerships and partners. The law requires that partnerships should file partnership returns, but that the tax should be charged on individual partners. Using the International Financial Law Review website, we identified some of Uganda's top commercial law firms and their partners. We sampled sixty lawyers for tax compliance. Table 4 shows the results.

Table 4 Compliance of top lawyers for individual income tax

\begin{tabular}{|l|l|l|l|}
\hline & FY 2011/12 & FY 2012/13 & FY 2013/14 \\
\hline Total number of lawyers & 60 & 60 & 60 \\
\hline Paid individual taxes & 12 & 14 & 17 \\
\hline
\end{tabular}

The above statistics relating to the taxation of individuals underscore one important aspect: there is potential to increase revenue collection by improving enforcement measures on personal income taxes. One of the tax consultants interviewed reported that some of the individuals they advise voluntarily report on their contracts by filing returns with the URA. However, to the best of their knowledge, the latter has never audited the activities of these individuals (Interview with tax consultants). If the URA is to successfully tax HNWIs, it needs to buttress its operations as far as taxing individuals is concerned.

The statistics also reveal another aspect that will be discussed when analysing the issue of information sharing: there is still room to improve the efficiency of the e-tax system to ensure that the platforms of different URA departments automatically interface to optimise revenue collection. 


\subsubsection{Taxation of allowances}

Section 19 of the ITA provides that employment income includes 'the amount of any travelling, entertainment, utilities, cost of living, housing, medical or other allowance'. Employment income also includes the value of any benefit granted to an employee. In practice, particularly in the public sector, these allowances are not included in the taxable income of employees (Interview with URA Official). In September 2006, for example, parliamentary proceedings revealed that subsistence allowances given to MPs and lecturers at Makerere University were not subjected to tax (Parliament of Uganda 2006). These allowances, commonly known as per diems, vary depending on the government agency, and can be quite substantial. They often cover items such as allowances for attending workshops, travelling locally and internationally for training and research, accommodation, meals, and, more fundamentally, payments under projects where those involved get paid separately from their employment income. Government seminars and workshops often involve significant amounts (Parliament of Uganda 2011b):

- Shs.8.6 billion (approximately US $\$ 3.09$ million) in 2010 and a budget of Shs.7.8 billion (approximately US\$2.8 million) for 2011 in the Prime Minister's Office;

- Ministry of Public Service: Shs.720 million (approximately US\$0.26 million) in 2010 and a budget of Shs.2.12 billion (approximately US $\$ 0.76$ million) for 2011;

- Ministry of Local Government: Shs.6.56 billion (approximately US\$2.35 million) in 2010 and a budget of Shs.8.83 billion (approximately US $\$ 3.17$ million) in 2011;

- Ministry of Finance: Shs.6.3 billion (approximately US\$2.26 million) in 2010 and a budgeted Shs.11.02 billion (approximately US\$3.95 million) for 2011; and

- Ministry of Water and Environment: Shs.4.75 billion (approximately US\$1.7 million) in 2010 and a budget of Shs.7.12 billion (approximately US\$2.55 million) for 2011.

Payments under independent projects within government agencies and universities often involve even bigger amounts, yet the income earned from them often goes untaxed. This translates into two things. First, there is loss of tax revenue. Second, there is an unfair application of tax laws, particularly given the fact that some employers in the private sector subject these allowances to tax.

\subsubsection{Optimisation of Tax Identification Numbers (TINs)}

The law requires each taxpayer to have a unique identifier called a Tax Identification Number (TIN), which is to be included in all their tax returns and correspondence with the URA. In practice, there are instances when the URA relaxes the requirement to use TINs. One example relates to the use of the e-tax system, where business entities are required to provide TINs for all their employees before they can use the system. The URA relaxed this rule when it was established that some employees did not have TINs (Interview with Tax Consultants). While one can appreciate the URA's predicament, this relaxing of rules translates into a difficulty in identifying individuals who have more than one employer. It also means that these individuals can avoid their obligation to file personal returns and dodge taxes.

\subsubsection{Other disconnects between theory and practice}

Other examples of the disconnect between the law and administration of the same include:

(a) Rarely implementing the provision of the ITA which requires that persons transferring funds in excess of 2500 currency points to a place outside Uganda should obtain a tax clearance certificate from the URA (Interview with Tax Consultants); 
(b) Rarely implementing the provisions relating to the taxation of trusts (Interview with Tax Lawyer). In practice, this has been made difficult by the fact that frequently the wealth inherited is not properly documented - it is part of the informal sector.

The above shortcomings in tax administration directly impact the URA's ability to increase tax revenue, and, unless addressed, will negatively impact its ability to tax HNWIs effectively.

\section{Management and exchange of information}

Effective tax administration depends on collaboration between revenue authorities and a network of actors including other government agencies, banks, employers, utility companies, professional bodies and revenue authorities in other countries (Moore 2013). More specifically, the ability to identify and tax HNWIs relies heavily on the ability of revenue authorities to access information from various sources. Section 131 of the ITA gives the URA the right to access taxpayer information, including the right to seize, retain, and make copies of the information. To ensure that the privacy of information is safeguarded, all URA officials gaining access to taxpayer information are required to keep it confidential (Section 157). Information access has been enabled through various avenues.

\subsection{Channels for sharing information}

There are various mechanisms in place to enable the URA to access taxpayer information. We discuss these below.

\subsubsection{Sharing of information within the URA}

There are three main electronic systems used by the URA to manage information: the e-tax system, ASYCUDA World, and SunSystems. These three systems deal with different aspects of information management. E-tax is used for domestic taxes. ASYCUDA World is for customs data (international taxes), and SunSystems collects information on expenditure and payment of suppliers, taxpayers and staff members. All three systems have a built-in mechanism that red-flags inconsistencies and allows for the sharing of information between the different departments of the URA. For example, domestic tax officials are able to match the declarations made on importation of goods with those made for purposes of domestic taxes (such as input VAT), to ensure that the information is coherent.

Additionally, in 2014, the URA established a Joint Compliance Committee (JCC) with the objectives of: improving collaboration between URA departments, reducing the interruption of taxpayer activities through conducting joint audits for domestic taxes, customs and tax investigation, and promoting efficient utilisation of scarce resources by conducting joint sector training and taxpayer education activities. The JCC analyses internal and external data to develop risk indicators by sector. During FY 2014/15, the JCC audited ten cases, which resulted in assessments totalling Shs.55.77 billion (approximately US $\$ 20.01$ million). For FY 2015/16, the JCC conducted rigorous tax compliance analyses, which were subsequently used to develop focus areas for the URA to concentrate on during the financial year.

\subsubsection{Memoranda of Understanding}

The URA has concluded memoranda of understanding (MOUs) with agencies inside and outside Uganda to facilitate the exchange of information. Within Uganda, it has entered into 
MOUs with institutions such as KCCA, URSB, Bank of Uganda, Uganda Bureau of Statistics, the FIA, Ministry of Trade, National Drug Authority, Uganda Manufacturers' Association, Public Procurement and Disposal of Assets Authority, Uganda Communications Commission, National Social Security Fund and the Institute of Certified Public Accountants. Outside Uganda, the URA has MOUs with other East African Community (EAC) revenue agencies (Rwanda, Burundi, Kenya and Tanzania), South Sudan, South Africa, United States of America, and development partners including the Department for International Development, KfW and Trade Mark East Africa.

These MOUs facilitate the sharing of taxpayer information and learning through best practice. By entering into an MOU with KCCA, for example, the URA is able to access the latter's property register and obtain information on businesses that have been issued with trading licences that might not be on the URA register. Similarly, the FIA has, since the beginning of its operations in late 2014, shared eight cases of suspicious transactions with the URA's Tax Investigations Department (Interview with FIA official). Most of these cases involve foreign individuals who use their personal bank accounts to undertake company transactions. Because the URA has not placed enough emphasis on taxing individuals, these foreign individuals bank money in their personal accounts and later repatriate it to their home countries. In this way, most of the money goes untaxed. Cooperation between FIA and the URA is also important because of the extensive network of MOUs that the FIA has with other countries in the region. ${ }^{5}$ It remains to be seen whether the URA will utilise this avenue to improve compliance. Lastly, while the MOU that the URA has with the other four East African countries is not for exchange of taxpayer information, it provides a platform for tax administrators to exchange ideas on how to deal with various challenges and to share research on issues that they have investigated, thereby promoting best practice (Interview with URA official).

\subsubsection{Exchange of information through Double Taxation Agreements (DTAs)}

Uganda does not have any Exchange of Information agreements on tax issues. However, it has DTAs that contain provisions on exchange of information. At the time of writing, Uganda had ratified DTAs with nine countries: Zambia (1968), United Kingdom (1993), Norway (2001), South Africa (2001), Denmark (2001), India (2004), Mauritius (2004), Italy (2005) and the Netherlands (2006). There are also a number of treaties which are at different stages of negotiation, including those with the EAC, Egypt, China, Belgium, United Arab Emirates and Seychelles.

Information normally exchanged under these agreements includes company shareholding, dividend payments, management fees, tax returns, payments of royalties, interest and capital gains (Interview with URA official). Prior to 2014, the competent authority under most of these DTAs was the Ministry of Finance. Revenue officials often raised the concern that this resulted in too much bureaucracy and delays in the process of responding to information requests. Since March 2014, the Tax Investigations Department in the URA is the Competent Authority. It has made eight requests for information since then, and received four requests, all of which have been responded to.

In addition, Uganda is a member of the OECD's Global Forum on Transparency and Exchange of Information in Tax Matters and the African Tax Administration Forum, both of which advocate exchange of information between member states. In November 2015, Uganda signed the Multilateral Convention on Mutual Administrative Assistance in Tax Matters, which will enable the URA to have access to information on its residents that have 
commercial dealings in any of the eighty-nine other countries that are participating in the convention (OECD 2015).

\subsubsection{Other sources of information}

There are various other channels of information to the URA including informers, moles, stamp duty paid on land transactions, non-governmental organisations, the police, and economic desks of other government agencies such as the Internal Security Organisation and the External Security Organisation. The URA has a toll-free number, a budget and a unit in charge of handing informers. An estimate of Shs.28.4 billion (approximately US $\$ 10.19$ million) is collected annually through information provided by informers (correspondence with URA official).

\subsection{Obstacles to sharing information within the URA}

The above mechanisms provide important inroads to taxpayer information. However, exchange of information is still undermined by several factors.

\subsubsection{Competing interests in URA departments}

One of the biggest challenges that was identified as undermining information sharing within the URA is the silo mentality between departments (Interviews with URA officials). Even with the existence of the JCC, departments often have independent plans and targets, which dictate their priorities. Sometimes there are competing priorities. For example, those in the core operation departments may be more interested in meeting their revenue targets than in helping with the compiling of evidence that may result in the prosecution of an individual taxpayer. This leads to concentrating on collecting whatever little they can from that taxpayer, instead of working with another department to build a stronger case that could subsequently be used to deter other taxpayers from evasion.

\subsubsection{Weaknesses in automated processes}

In addition, while the URA has made significant progress in automating its services, there are certain limitations on the use of these systems. To begin with, even though these systems contain a wealth of information, they do not automatically flag inconsistencies in the different databases. Detecting these inconsistencies is a manual exercise, which largely depends on the diligence and impulse of the revenue officials dealing with the cases. Also, in a move to safeguard the sanctity of what is often sensitive information, only authorised personnel have unlimited access to systems such as e-tax. For example, out of the forty staff members in the Research, Planning and Development Department, only seven officials have access to the e-tax system (Interviews with URA officials). This access is further restricted to dynamic reports, which do not provide the comprehensive picture necessary for the analytical work required by a research department.

\subsubsection{Limitations to accessing information from third parties}

One important source of taxpayer information is commercial banks. During interviews, various URA officials cited difficulties in accessing information from banks. They highlighted various obstacles to access: (i) the URA is only able to access this information if it is in possession of an agency notice; (ii) the Central Bank sometimes interferes with the process of accessing information by protecting commercial banks; (iii) banks sometimes collude with their customers to hide information from the URA; (iv) banks sometimes refuse to provide the URA with information such as that relating to lists of clients' bank accounts; and (v) slow response to the URA's requests. On the whole, it appears that the difficulties faced by the URA in accessing information from banks result from two factors. First, some officials are 
unaware of the fact that Section 131 of the ITA gives the URA unqualified access to information that is in the possession of taxpayers, which covers bank accounts. Second, access is often unsuccessful because of the manner in which URA officials make their requests. In our interviews with officials from the Bank of Uganda and the commercial bank, for example, it was noted that where the URA has failed to access information, it has been because: (i) those requesting the information do not appear to know exactly what information they are looking for at the time of making the request; (ii) they do not ask the right questions; or (iii) they are not specific enough in the requests that they make.

There are a number of challenges as far as sharing information with other government agencies is concerned. To begin with, many of these agencies are at different levels of automation or use different technology. One of the major challenges to sharing registration information between KCCA and the URA under the TREP project, for example, is that e-tax and KCCA's ECITIE are not interfaced, which results in delays in the sharing of information and analysis of data (TREP Report 2015). Other government agencies, such as the land registry, pose even bigger challenges because of the low levels of automation. Second, some of the information found in these agencies is outdated, inaccurate or misplaced. Third, the URA does not have a good working relationship with some government agencies such as the Ministry of Lands. There have been reports, for example, of the URA being required to pay fees in order to conduct searches on land titles which are in possession of the land registry (Interview with Revenue official).

Lastly, while MOUs are an important source of information, their effectiveness is limited largely by the fact that there is no central place for managing them. The URA's legal department drafts and/or peruses through these agreements to ensure that the URA's interests are protected. However, different departments or divisions within departments initiate the agreements. Those who initiate them have the responsibility of managing, implementing and monitoring the agreements. The challenge of lacking a central place of management is that, sometimes, officials in other departments are not aware of the existence of an MOU, and so will not utilise it. Even if they were to become aware of the existence of an MOU, the fact that it was not signed with them may pose some challenges in attempting to obtain information from the third party.

\subsubsection{Accuracy and comprehensiveness of data}

Sometimes the information possessed by the URA is inaccurate and/or incomplete (Interviews with URA officials). For example, an analysis of the taxpayer register for purposes of this research revealed that over 16 per cent of company directors declared wrong TINs when registering companies. Some of them used old TINs that have been phased out, while others inserted TINs in the wrong format. ${ }^{6}$ Revenue officials also reported that often taxpayers provide inaccurate and/or incomplete information regarding their contacts and location. Lastly, there are also inconsistencies between information contained in the assets register and the stamp duty register (Interview with URA official). These inconsistencies undermine the potential of data matching exercises.

The above shortcomings are exacerbated by two other factors. First, TINs are often issued without undertaking a detailed verification of the person seeking to be registered. The result is that the same individual can have more than one TIN by changing some aspect of their identity. Second, the URA has no team that is dedicated to examining the strengths and weaknesses of the registration process. If such a team were in place, it would have flagged out cases of duplicate TINs, and identified cases of low productivity or inaction of registered persons (Interview with URA official).

There is, however, an on-going exercise to clean up these records through the e-tax system. 


\subsubsection{Capacity of URA officials to utilise data}

Many of those interviewed within the URA observed that, while there is wealth of information, there is limited capacity to analyse the data. For example, the Business Intelligence Unit of the Research and Planning Department only has two staff members. Other officials in the research department are over-stretched because of multiple projects with few revenue officials. This is a challenge for most other departments. As such, there are a number of checks which are not undertaken. For example, not enough analysis is going into the scrutiny of land transactions, to match stamp duty payments with tax compliance (Interview with URA officials).

\section{Taxing HNWIs in Uganda: a preliminary approach}

The URA's approach to taxing HNWIs ought to take a two-pronged approach. The first set of remedies should be targeted at the taxpayers, and involve various considerations. First, the URA needs to be awake to the political and instrumental power enjoyed by these individuals. Second, it should have strategies in place to address the high levels of non-compliance. Some cases of non-compliance are deliberate. Others are a result of taxpayers' ignorance of their obligations. Each of these should be treated differently. Third, mechanisms should be developed to deal with the prevalence of the informal sector. The second set of remedies should be geared towards the URA in particular and government in general. First, both the URA and the government need to critically examine the reasons behind the high levels of non-compliance. Second, the government needs to take bold steps to address the problem of the informal sector. Third, the URA should continue building the capacity of its staff. We briefly discuss these proposals, and emphasise that our recommendations here serve simply as a preamble to our next task. We shall explore the recommendations in more detail in the second phase of this project, which will provide more concrete guidance.

\subsection{Approaches targeted at taxpayers}

\subsubsection{Encouraging quasi-voluntary compliance}

Tax experts agree that it is difficult, if not impossible, to achieve complete voluntary compliance (Moore 2013; Everest-Phillips 2009; Therkildsen 2001). They argue that quasivoluntary kind of compliance is more attainable: compliance that is defined by limited resistance from taxpayers because they appreciate the role of taxes. This involves tax bargains (Kangave and Katusiimeh 2015; Therkildsen 2001). As already noted, one of the challenges with taxing this group of individuals is that they are either politicians or politically connected. For this reason, most interviewees agreed that perhaps the most effective approach would be to identify the individuals, explain to them what is meant by HNWIs, and then engage in dialogue with them about the importance of taxes and their contribution to the same. This approach takes cognisance of the fact that coercion is costly and should only be applied in cases where quasi-voluntary compliance fails. It also acknowledges that elites are not necessarily anti-development; they may be driven by self-interest, but they are central to reform processes (DiCaprio 2014).

Because of the nature of the individuals involved, there is need for political buy-in at the topmost level of government and URA management. In the end, as long as these individuals remain compliant, their relationship with the URA and government should be one of partnership, working together to ensure that compliance is improved on the one hand, and 
government is made accountable for taxes on the other hand. In Colombia, the government was successful in imposing a security tax on elites primarily because of three reasons: (a) fiscal and economic conditions in the country, which dictated that the government declare a state of emergency requiring the adoption of a tax decree; (b) solidarity and cohesion between government and business elites; and (c) improved perceptions that the government was in position to account for the taxes through the provision of security (Flores-Macías 2012).

This approach of negotiating with taxpayers is an example of the cooperative compliance advocated by the OECD (OECD 2009). It ensures that, at least for those that prove to be compliant, the costs of using coercion are reduced. Given the fact that the URA is constrained by financial and human resources, this method would release resources to be targeted at those who are less compliant.

\subsubsection{Dealing with non-compliance: tax education and tax amnesties}

Not all non-compliance is deliberate. Some taxpayers are ignorant of their taxpaying obligations. Those working on the Rental Project found that many individuals do not know that taxes should be paid on residential rental properties (Interview with URA officials). Similarly it has been noted that, frequently, taxpayers believe that once their PAYE is withheld or they have paid customs duties, their tax obligations are fulfilled - even though they generate income from other commercial activities (Interviews with URA officials). Even highly-educated individuals do not always appreciate the interpretations of tax legislation. For example, because Article 128 (7) of the Constitution prohibits the salaries, allowances and benefits of judicial officers from being varied to their disadvantage, some judicial officers have interpreted this to mean that all their income (even that outside their employment) is exempt from tax (Interview with URA official).

The URA conducts various tax clinics to sensitise taxpayers on their rights and obligations. However, more needs to be done. There is a need for a tax education strategy that challenges the taxpaying culture (Interview with URA official). The URA should develop a strategy that is specifically geared towards the needs of HNWIs, because empirical evidence shows that they rarely, if at all, attend the general tax clinics currently run by the URA (Interview with URA official).

The tax strategy should, among other things, provide a better understanding of the operations of the URA, in order to clean up the negative image that taxpayers have of the organisation. Some taxpayers complain, for example, that the URA often takes an aggressive and unfair approach to the interpretation of tax laws (Interview with tax consultants). Others fear the URA because they believe that any contact with it will result in taking away their property (Interview with URA official). Often, after URA officials explain how taxation works, many of these individuals wish that they had engaged with it earlier instead of using 'quack' advisors who sometimes end up costing them more because of the resulting tax exposure.

The government should consider giving a tax amnesty to encourage more HNWIs to disclose their incomes. In 2007, the government provided an amnesty by waiving interest and penalties on taxes for those who voluntarily disclosed their tax liability (Parliament of Uganda 2008). As a result of the amnesty, the URA collected Shs. 41 billion (approximately US $\$ 14.71$ million), and brought new taxpayers onto the register. While this amnesty was undeniably useful in increasing revenue collection, some wonder whether it would not have achieved more if it had been structured differently (Interview with tax practitioner). It is not clear how many new taxpayers were brought onto the register, but, if the taxes collected are any indication, it is quite likely that most of these taxes were collected from taxpayers who were already on the register but who had not been fully compliant. To target the large 
informal sector, tax amnesties should be structured so that they encourage previously fully non-compliant parties to voluntarily identify themselves. This would entail not only waiving interest and penalties, but also waiving the principal taxes, because these can be quite substantial and would discourage people from coming clean (Interview with tax practitioner).

Experts have warned against treating amnesties as the panacea to non-compliance (Fjeldstad et al. 2014). They argue that, for amnesties to be successful, they need to go beyond providing relief for past non-compliance. Amnesties should influence behavioural changes by increasing the likelihood that future non-compliance will be punished. For this reason, they ought to be perceived by taxpayers as 'onetime opportunities to redress tax violations' (Uchitelle 1989). They should also be followed with strict enforcement measures.

The URA should advertise the introduction of the new segment of HNWIs as a one-time opportunity for these individuals to benefit from disclosing their income without fear of being penalised. To ensure that the amnesty is successful, several measures should be taken:

- Announce the amnesty at the same time as announcing the URA's decision to embark on the project for taxing HNWls;

- Set out a comprehensive strategy for educating HNWIs on their tax obligations, their rights as taxpayers, and provide accountability for the taxes collected. The education strategy should consist of top-level management visits to individual taxpayers, and allocating URA officials to these individuals with the aim of helping them to clean up their books;

- To ensure that unidentified individuals are reached, communication about the amnesty should not be limited to budget speeches and parliamentary debates that individuals rarely listen to. It should be communicated on local television and radio stations, and through national and local government agencies such as the KCCA, Ministry of Lands and Ministry of Finance;

- Remind taxpayers that the amnesty is a one-time opportunity, and that any noncompliance will be punished. This should be followed up with an increase in audits on individuals and the enforcement of the law against those who do not comply.

\subsubsection{Dealing with deliberate non-compliance}

The recommendations made above will result in increased compliance. However, for those that have thrived from being informal, or those acquiring income from unexplained sources, more creative methods need to be employed.

One method that should be applied more is to rely on consumption patterns to estimate income (Ministry of Finance). This would entail tracing the consumption patterns of individuals, including the land transactions that they undertake, cars that they drive, the kind of houses that they own, frequency of international flights (particularly in business or first class), and individuals making frequent transfers of large sums of money. These transactions should then be used to make presumptive tax assessments, which would have the effect of shifting the tax burden to the taxpayer. At least one URA official has warned that lifestyle choices in Uganda are not indicative of income levels, because most of those living flashy lifestyles simply do so to show off, without necessarily being wealthy. However, given the large informal sector, consumption patterns are important in raising assessments, at the very least for the purpose of shifting the tax burden. The URA has made three attempts in this regard, which, while achieving limited success, have the potential to help with the identification of HNWIs if properly executed.

In 2011, the URA introduced a system requiring that persons buying land valued at more than Shs.50,000,000 (approximately US $\$ 17,941$ ) should obtain income tax clearance 
indicating the purchaser's source of income, before the land could be registered in their name. Given the importance of land as a symbol of wealth, this initiative was a move in the right direction. However, it was soon politicised and subsequently stopped before the URA could generate any meaningful information. The URA should consider reintroducing this with the support of top government officials.

More recently, the URA made another attempt to tax consumption patterns (Interview with URA official). It developed a list of high value cars, which was used as a basis for raising presumptive taxes on the vehicle owners. Most of the cars in question also had personalised number plates (which are more expensive than ordinary number plates). The URA's enforcement division then issued warrants to the owners of the cars and, in some cases, attached the cars. Some taxes were collected through this drive. However, the process faced various challenges. First, in a number of cases, enforcement measures were undertaken before making attempts to engage the taxpayers in a more cordial manner - an approach that would have resulted in establishing better facts about the potential taxpayer. Second, some of the assessments raised by URA officials were not grounded in proper investigations to establish reasonable values for the cars, resulting in over-estimations. In the end, the exercise achieved only limited success. However, the important lesson is that is raised some taxes and resulted in adding a few taxpayers onto the register.

The third approach involves a bold move by the URA to tax illicit wealth (specifically from corruption-related scandals). Using information obtained from the Criminal Investigations Department in the Uganda Police, the land registry, KCCA and field operations, the URA is investigating seven companies and three individuals implicated in corruption scandals (correspondence with URA official). Taxes worth approximately Shs.5 billion (approximately US\$1.79 million) have been assessed, and the URA's Debt Collection Unit is trying to recover them. This approach is not without challenges. To impose a tax on public funds that the government is trying to recover poses a predicament (Interview with tax lawyer). Can the money be referred to as taxable income of the individual when the government is also claiming the same money? What happens if the courts determine that the individual is guilty, and, as such, should refund the money? This approach is not ideal. But it is important for various reasons. First, it recognises the vast amounts of wealth associated with illicit income. Second, it seeks to tax income that may be difficult to trace after it has been invested or taken offshore. Third, it seeks to return to public coffers part of what has been illegally removed. Where persons are found accountable yet have already paid tax on this income, the ITA has provisions to refund overpaid taxes. Fourth, this approach may serve to deter public officials from engaging in corruption.

What is important about the above three approaches is not that they have shortcomings. They are important because they use non-conventional approaches to deal with issues that do not lend themselves well to simple solutions. If properly thought through, these approaches have the potential to bring more taxpayers onto the register, and reduce the number of those operating informally.

\subsection{Approaches targeting the URA and government}

\subsubsection{Building tax morale}

Everest-Phillips argues that elites are more likely to pay taxes when they share the conviction that taxation is necessary for their benefit and that of the country's long-term future (Everest-Phillips 2009). Similarly, Therkildsen notes that 'Quasi-voluntary compliance will occur when taxpayers have confidence that rulers keep their part of the contract, and other constituents keep theirs' (Therkildsen 2001). Effective taxation relies significantly on the legitimacy of the state as expressed in its ability to account for the taxes that it collects. To this end, it is important for the government of Uganda to reflect on the country's poor tax- 
paying culture. Many Ugandans are unwilling to pay taxes for a variety of reasons. First, they feel that the government does not provide the basic necessities that tax money should fund. While the government provides services such as universal primary and secondary education, and free healthcare in government hospitals, the poor quality of these services often means that even individuals who earn relatively low incomes have to resort to the private sector for services, resulting in a significant dent in their income. Second, tax morale is undermined by the frequent reports of corruption scandals, often involving the embezzlement of millions of taxpayer shillings by public servants. Third, the motivation to pay taxes is undermined by the fact that there are many freeriders who share in public benefits, but dodge their tax obligations.

No attempt at achieving a sustainable tax regime can be one-sided. Designing strategies aimed at ensuring compliance, without addressing the concerns of potential taxpayers, is bound to produce only limited success. Sustainable taxation is hinged primarily on the legitimacy of the state. Government thus needs to take measures to reduce corruption, improve the quality of public services and promote fair taxation, by ensuring that it not only taxes all individuals above the tax threshold, but also that people are taxed relative to their wealth.

\subsubsection{Tackling the problem of the informal sector}

There is an intimate relationship between the existence of a large informal sector and a country's ability to raise tax revenue (Moore 2013). While the URA acknowledges that there are shortcomings in tax administration, it also maintains that as long as the informal sector continues to constitute the bulk of the economy, and cash remains the dominant mode of transacting, it is unlikely that there will be any meaningful increase in the tax-to-GDP ratio (Interview with URA official). For this reason, the government needs to develop a strategy for shrinking the informal sector, minimising the use of cash.

Perhaps the biggest challenge to formalising the economy is the lack of a functional identification process. Most of those interviewed highlighted the fact that it is difficult to establish audit trails because of the lack of a proper identification system. Even in institutions such as banks, where identification documents are required, it is difficult to verify the authenticity of documents used (Interview with officials in the banking sector). For example, many of the reference letters that are provided by local council officials to support the opening of bank accounts are easy to forge. There are also many reports of local council officials being bribed to provide references.

The recent introduction of a national identification system has the potential to deal with some of the challenges posed by the informal sector. The National Security Information System project, operated by the Ministry of Internal Affairs, is aimed at identifying, registering and processing identity (ID) cards for eligible Ugandan citizens and foreign residents. ${ }^{7}$ The National ID cards include biological data, fingerprints and electronic facial features. ${ }^{8}$ For this ID to be effectively used to further tax collection, it ought to be used as the single identifier for a variety of official, business and some personal transactions including registering for taxes, opening bank accounts, registration of businesses, obtaining and renewing driving licences, land transfers and identification for immigration purposes. More importantly, the different institutions that collect this information need to develop systems which interface to ensure optimal use of the National ID for tax purposes. It is also important to ensure that there is a robust mechanism in place to keep the personal information of taxpayers safe and confidential.

National Information Technology Authority-Uganda, 'National ID' <http://www.nita.go.ug/projects/national-id>. National Security Information System, 'Frequently Asked Questions' <http://nsis.go.ug/faqs>. 


\subsubsection{Strengthening capacity of URA officials}

Improving tax administration to support the taxation of HNWIs will also entail improving the technical capacity of URA officials, both to undertake effective audits based on the limited information that is available (Interview with Official from the Ministry of Finance), and to internalise and analyse available data effectively. The URA has a wealth of information in its possession, but there are no dedicated personnel to analyse this information for the purpose of improving performance. Similarly, systems need to be put in place to evaluate the performance of the various programmes being run by the URA, such as TREP and the e-tax system.

\section{Conclusion: the way forward}

Experience from other jurisdictions attests to the fact that where economic elites have strong political and/or investment power, it is difficult to have significant increments in direct taxes (Fairfield 2013). However, modest revenue gains, which are quite important for struggling economies, are achievable when this group of individuals is targeted. In Colombia, for example, security taxes levied on elites between 2002 and 2010 contributed 5 per cent to tax revenue and 1 per cent to GDP (Flores-Macías 2012). Similarly, Uganda is likely to realise at least a modest increase in its tax revenue by taxing HNWIs. However, this exercise should be approached cautiously. Targeting these individuals should not mean increasing tax rates: this may result in more tax evasion, as those who feel unfairly targeted may increase operations in the informal sector. The additional 10 per cent tax on individuals earning an income of more than Shs.120,000,000 (approximately US\$43,057) per year results in an effective tax rate of 40 per cent on high income earners. If properly administered, a lot of tax revenue would be collected from this additional tax. In the end, an effective strategy for taxing HNWIs will need to recognise that an important component of increasing revenue collection is taxing better, not necessarily taxing more. To this end, improving tax administration in the various ways suggested in this paper is quite central to improving revenue collection.

To identify and tax Uganda's HNWls effectively, it will also be necessary to develop a comprehensive framework governing their taxation. Aspects to be addressed by such a framework include having a strategy to deal with the political problem; determining a threshold that is specific to Uganda's economic realities; establishing whether to have a separate unit dedicated to these individuals that is distinct from the LTO; examining the existing tax bands and tax rates; and designing alternative strategies to engage with these taxpayers, including the development of a tax education strategy. In the second phase of this project, we plan to benchmark the practices of taxing HNWIs in at least four other jurisdictions, before developing a comprehensive strategy for Uganda. 


\section{References}

\section{A. Articles, books and book chapters}

Alvaredo, F., Atkinson, A., Piketty, T. and Saez, E. (2013) 'The Top 1 Percent in International and Historical Perspective', Journal of Economic Perspectives 27(3): 3-20

Atkinson, A., Piketty, T. and Saez, E. (2011) 'Top Incomes in the Long Run of History', Journal of Economic Literature 49(1): 3 -71

Australian Tax Office (2008) Wealthy and Wise: A Tax Guide to Australia's Wealthiest People <http://www.traverseaccountants.com.au/wpcontent/uploads/A_tax_guide_for_Australias_wealthiest_people_copy.pdf>

Banage, S. (2013) 'URA's E-Tax System has Contributed to Increased Revenue', <http://www.monitor.co.ug/OpEd/Letters/URA-s-E-tax-system-has-contributed-toincreased-revenue/-/806314/1925336/-/eagv8oz/-/index.html>

Capgemini and RBC Wealth Management (2014) Population and Wealth of U.S. High Net Worth Individuals Reaches Record Levels as Wealth Creation Expands Beyond East and West Coasts, <http://www.rbcwealthmanagement.com/wealth-insightsresearch/thought-leadership/uswr/documents/USWR2014_PressRelease-DET.pdf>

(2013) World Wealth Report, <http://www.capgemini.com/resource-fileaccess/resource/pdf/wwr_2013_0.pdf>

de Jantcher, M. (1990) 'Administering the Value Added Tax', in M. Gillis, C. Shoup and G. Sicat (eds), Value Added Taxation in Developing Countries, Washington DC: The World Bank

DiCaprio, A. (2014) 'Introduction: The Role of Elites in Economic Development', in A. Amsden, A. DiCaprio and J. Robinson (eds), The Role of Elites in Economic Development, Oxford University Press

Economic Policy Research Centre (2013) Uganda 2013 FinScope III Survey Key Findings: Unlocking Barriers to Financial Inclusion,

<http://www.score.or.ug/uploads/FINSCOPE_\%201II\%20Survey_\%202013_\%20findi ngs.pdf>

Everest-Phillips, M. (2009) When Do Elites Pay Taxes? Tax Morale and State-Building in Developing Countries, WIDER Elites Conference 12 June 2009

Fairfield, T. (2013) 'Going Where the Money Is: Strategies for Taxing Economic Elites in Unequal Democracies', World Development 47: 42 - 57

- (2010) 'Business Power and Tax Reform: Taxing Income and Profits in Chile and Argentina', Latin American Politics and Society 52(2): 37-71

Fjeldstad, O-H., Jensen, S. and Paulo, F. (2014) 'Tax Amnesty in Angola: A Fresh Start or a Vicious Circle?', Angola Brief 4(9) 
Flores-Macías, G. (2012) Financing Security through Elite Taxation: The Case of Colombia's 'Democratic Security Taxes', ICTD Working Paper 3, Brighton: International Centre for Tax and Development

Global Financial Integrity (2010) Illicit Financial Flows from Africa: Hidden Resource for Development,

<http://gfintegrity.org/storage/gfip/documents/reports/gfi_africareport_web.pdf>

Henry, J. (2012) The Price of Offshore Revisited: New Estimates for 'Missing' Global Private Wealth, Income, Inequality, and Lost Taxes,

<http://www.taxjustice.net/cms/upload/pdf/Price_of_Offshore_Revisited_120722.pdf>

High Level Panel on Illicit Financial Flows from Africa (2015) Illicit Financial Flows, $<$ http://www.africa-

platform.org/sites/default/files/resources/report_of_the_high_level_panel_on_illicit_fina ncial_flows_from_africa_2015.pdf>

Human Rights Watch (2013) 'Letting the Big Fish Swim: Failing to Prosecute High-Level Corruption in Uganda', <https://www.hrw.org/report/2013/10/21/letting-big-fishswim/failures-prosecute-high-level-corruption-uganda>

Kangave, J. and Katusiimeh, M. (2015) Tax Bargains: Understanding the Role Played by Public and Private Actors in Influencing Tax Policy Reform in Uganda, UNRISD Working Paper 2015-2

Kangave, J. (2005) 'Improving Tax Administration: A Case Study of the Uganda Revenue Authority', Journal of African Law 49(2): 145-176

Knight Frank (2014) The Wealth Report, $<$ http://www.thewealthreport.net/resources/thewealthreport2014.pdf>

Mahon Jr., J., Bergman, M. and Arnson, C. (eds) (2015) Progressive Tax Reform and Equality in Latin America,

$<$ https://www.wilsoncenter.org/sites/default/files/ProgressiveTaxReform_Equality.pdf>

Ministry of Finance, Planning and Economic Development, Uganda (2015) Budget Speech: Financial Year 2015/2016, <http://www.judicature.go.ug/files/downloads/268370038Budget-Speech-for-the-financial-year-2015-2016.pdf>, accessed 16 July 2015

— (2014) Budget Speech: Financial Year 2014/2015, <http://www.parliament.go.ug/new/images/stories/speeches/bud14.pdf>

_ (2013) Budget Speech: Financial Year 2013/2014, <http://www.budget.go.ug/budget/sites/default/files/National\%20Budget\%20docs/Budg et\%20Speech\%202013-14_13th\%20June\%202013.pdf>

Moore, M. (2013) Obstacles to Increasing Tax Revenues in Low Income Countries, ICTD Working Paper 15, Brighton: International Centre for Tax and Development

Mulondo, M. (2014) 'URA to Collect Taxes on Rented Houses, Properties', $<$ http://www.newvision.co.ug/news/657957-ura-to-collect-tax-on-rented-housesproperties.html> 
Murangira, J. (2014) 'A Critical Analysis of the Right to Equality before the Law in Property Rates Tax Law and Practice in Kampala Capital City Authority', Merit Research Journal of Art, Social Science and Humanities 2(8): 115 - 120

National Economic Council (2012) The Buffett Rule: a Basic Principle of Tax Fairness, $<$ https://www.whitehouse.gov/sites/default/files/Buffett_Rule_Report_Final.pdf>

Nyambura, S. (2015) 'Uganda's Billionaires that are Under 40', The CEO Magazine, <http://www.theceomagazine-ug.com/blog/2015/03/16/ugandas-billionaires-under-40/>

OECD (2015) 'Uganda Becomes the $90^{\text {th }}$ Jurisdiction to Join the Most Powerful Multilateral Instrument Against Offshore Tax Evasion and Avoidance', http://www.oecd.org/ctp/exchange-of-tax-information/uganda-becomes-the-90thjurisdiction-to-join-the-most-powerful-multilateral-instrument-against-offshore-taxevasion-and-avoidance.htm

_ (2009) Engaging with High Net Worth Individuals on Tax Compliance, $<$ http://www.keepeek.com/Digital-Asset-Management/oecd/taxation/engaging-withhigh-net-worth-individuals-on-tax-compliance_9789264068872-en\#page1>, accessed 4 May 2015

Parliament of the Republic of Uganda (2011a) Parliamentary Debates: Hansard, 10 October, Kampala

_ (2011b) Parliamentary Debates: Hansard, 25 August, Kampala

_ (2008) Parliamentary Debates: Hansard, June 2008, Kampala

_ (2006) Parliamentary Debates: Hansard, September 2006, Kampala

Piketty, T., Saez, E. and Stantcheva, S. (2014) 'Optimal Taxation of Top Labor Incomes: a Tale of Three Elasticities', American Economic Journal: Economic Policy 6(1): 230-271

Ssempebwa, A. (2014) 'Taxpayer Registration Project to Tax into Informal Sector', $<$ http://observer.ug/component/content/article?id=30052:-uras-tax-register-expansionproject-to-tap-into-informal-sector->

Sserunjogi, E. (2015) 'Swiss Bank Links Secret Shs. 250b to Ugandans', $<$ http://www.monitor.co.ug/News/National/7-Ugandans--hiding--billions-Swiss-bank//688334/2618750/-/item/0/-/15bvm7fz/-/index.html>

South African Revenue Service (2014) 2014/2015 - 2018/19 Strategic Plan, <http://www.sars.gov.za/AllDocs/SARSEntDoclib/Ent/SARS-Strat-12\%20\%20SARS\%20Strategic\%20Plan\%202014\%202015\%20to\%202018\%202019.pdf>

- (2012) 'Briefing Note: Update on SARS Compliance Programme', <http://www.sars.gov.za/Media/MediaReleases/Documents/UpdateonSARSComplianc eProgramme201213.pdf>

Tata Consultancy Services (2011) Uganda Revenue Authority Implements an Integrated Tax System with the Support of TCS, <http://www.tatauganda.com/downloads/Government_CaseStudy_Uganda_Revenue_ Authority_integrated_tax_system_05_2011.pdf> 
Therkildsen, O. (2001) 'Understanding Taxation in Poor African Countries: A Critical Review of Selected Perspectives', Forum for Development Studies 1: 99-123

Uchitelle, E. (1989) 'The Effectiveness of Tax Amnesty Programs in Selected Countries', FRBNY Quarterly Review pp. 48 - 53

Uganda Revenue Authority (undated) Taxpayer Register Expansion Project (TREP) to Tap into the Informal Sector, <https://www.ura.go.ug/download/CGMS/TREP_FINAL.pdf>

Uganda Bureau of Statistics (2014) GDP Estimates Rebased to 2009/10, <http://www.ubos.org/onlinefiles/uploads/ubos/GDP/Rebased\%20GDP\%20Estimates $\% 202009-2010 . p d f>$

- (2009) Uganda National Household Survey Report 2009/2010, <http://www.ubos.org/UNHS0910/chapter12_the\%20informal\%20sector.html>, accessed 16 July 2015

World Bank (2013) Uganda: About the Second Economic Update, <http://www.worldbank.org/content/dam/Worldbank/document/Africa/Uganda/Report/u ganda-economic-update-august-2013-summary.pdf>, accessed 16 July 2015

Wurzinger, M, Ndumu, D., Okeyo, A. and Sölkner, J. (2008) 'Lifestyle and Herding Practices of Bahima Pastrolists in Uganda', African Journal of Agricultural Research 3(8): 542548

\section{B. Laws}

The Income Tax Act Cap 340

The Anti-Money Laundering Act, 2013

The Uganda Revenue Authority Act Cap 196

C. URA Internal Documents (unpublished)

The Taxpayer Register Expansion Project (TREP) Report, 2015

Uganda Revenue Authority Internal Report, 2014

Uganda Revenue Authority databases from FY 2004/05- FY 2014/15 (e-tax and

ASYCUDDA) 


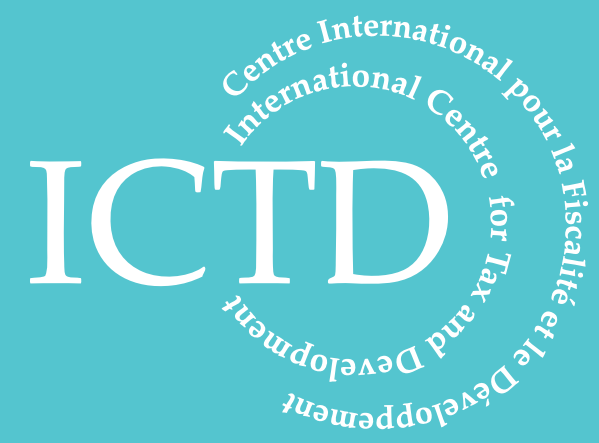

International Centre for Tax and Development at the Institute of Development Studies

Brighton BN1 9RE, UK

T: +44 (0) 1273606261

F: $+44(0) 1273621202$

E: info@ictd.ac

www.ictd.ac 